\title{
How local stakeholders perceive agroforestry systems: an Italian perspective
}

Camilli Francesca ${ }^{1 *}$, Andrea Pisanelli ${ }^{2}$, Giovanna Seddaiu ${ }^{3}$, Antonello Franca ${ }^{4}$, Valerio Bondesan ${ }^{5}$, Adolfo Rosati ${ }^{6}$, Gerardo Marcos Moreno ${ }^{7}$, Anastasia Pantera ${ }^{8}$, John E Hermansen ${ }^{9}$, Paul J Burgess ${ }^{10}$

1 Institute of Biometeorology, National Research Council. Via Caproni 8, 50143, Florence, Italy

2 Institute of Agro-Environmental and Forest Biology, National Research Council, V. le Marconi 2, 05010

Porano TR Italy

3 Department of Agriculture Sciences, Sassari University. Viale Italia 39, 07100, Sassari, Italy.

4 Institute for the Animal Production System in the Mediterranean Environment, National Research

Council, Traversa La Crucca, 3 - Localita' Baldinca - 07040 Li Punti, Sassari, Italy

5 Veneto Agricoltura, Regional Agency for Agriculture, Forestry and Agrifood Sectors, Viale dell'Università, 14 - 35020 Legnaro PD, Italy

6 Consiglio per la Ricerca in Agricoltura e l'Analisi dell'Economia Agraria, Centro di Ricerca per

I'Olivicoltura e I'Industria Olearia, CREA OLI, Via Nursina, 2, Spoleto PG, Italy

7 Forestry School, University of Extremadura, Plasencia, Avd. Virgen del Puerto, 10600 Plasencia, Spain.

8 Dept. of Forestry \& N.E.M., TEl of Central Greece, Greece

9 Department of Agroecology, Aarhus University, Nordre Ringgade 1, DK-8000 Aarhus C Aarhus, Denmark

${ }^{10}$ Cranfield University, Cranfield, Bedfordshire, College Road, Cranfield MK43 OAL, UK

Corresponding author: Francesca Camilli, f.camilli@ibimet.cnr.it

\section{Abstract}

This paper reports the study conducted in Italy, within the AGFORWARD (2014-2017) project, aimed at promoting innovative agroforestry practices in Europe. Agroforestry offers a means of maintaining food production whilst addressing some of the negative environmental effects of intensive agriculture. This study aims at eliciting the positive and negative points of views and perceptions of local stakeholders in Italy in relation to three types of agroforestry system. The Participatory Research and Network Development (PRDN) was implemented in three workshops conducted in Sardinia, Umbria, and Veneto regions, and applied adopting a common methodological protocol. Qualitative data were obtained using open discussions with stakeholders on key issues, challenges and innovations. Quantitative data were obtained from stakeholders completing questionnaires during the workshops. A statistical analysis was applied to elicit the differences in positive and negative perceptions of the stakeholders in relation to production, management, environment and socio-economy aspects. Even though the participants to this study came from different geographical and socioeconomic contexts with different educational and cultural backgrounds, they generally shared similar perceptions of the benefits and constraints of across different professional groups (farmers, policy makers and researchers) and the three workshops. The effects of agroforestry on production and the environment were generally perceived as positive, whilst those related to management were generally negative. The process of bringing the groups together seemed to be an effective means of identifying the key researchable gaps that need to be addressed in order to promote the uptake and maintenance of agroforestry.

Key words: Agroforestry, EU policy, Innovation, Landscape, Ecosystem services 


\section{Introduction}

Agroforestry is a land use practice in which woody perennials (trees or shrubs) are integrated with crops and/or animals on the same land unit (Nair 1993; Burgess et al. 2015). Such practices have shaped key features of the rural landscape of Mediterranean countries where trees have traditionally been deliberately retained or included in the cultivated or grazed lands by farmers. The trees have provided secondary products such as fruits, fodder for livestock and wood for fuel, litter or timber as well as environmental benefits (Eichhorn et al. 2006).

During the second half of $20^{\text {th }}$ Century, trees were progressively removed from the cultivated land as a result of mechanization and as a consequence of land consolidation schemes to increase the size of agricultural parcels. However, the adoption of intensive agriculture has also been associated with undesirable environmental consequences such as loss of biodiversity, soil erosion, and water and groundwater pollution. Hence in recent decades there has been an increased interest in using agroforestry to enable continued food production with environmental benefits (Shibu 2009; Palma et al. 2007). Various authors have shown that multifunctional agroforestry can be productive and profitable whilst also diversifying the sources of farm income (Graves et al. 2007; Rossetti et al. 2015; Barbieri and Valdivia 2010; Nair et al. 2010; Smith et al. 2013).

Following the Silvoarable Agroforestry for Europe (SAFE) project (Dupraz et al. 2005), the Common Agricultural Policy (CAP) recognised that the establishment of agroforestry should be encouraged because of its "high ecological and social value" (Council Regulation (EC) No 1698/2005). A financial mechanism was subsequently introduced in the 2007-2013 EU Rural Development Programmes (RDPs) to support the first establishment of new agroforestry systems on arable land. Agroforestry systems continue to receive support according to the Article 23 of the Regulation 1305/2013 in the 2014-2020 rural development programme (Pisanelli et al. 2014).

In this framework, the project AGFORWARD AGroFORestry that Will Advance Rural Development (www.agforward.eu), funded by the European Commission within the FP7, is aimed at promoting agroforestry practices in Europe that will advance sustainable rural development (Burgess et al. 2015). One of the project objectives is to identify, develop and field-test innovations to bridge the current research gaps concerning agroforestry systems.

This paper shows the main findings emerging from the application of the Participatory Research and Development Network (PRDN) methodology to three case studies implemented in Italy within the AGFORWARD project. The overall objective is to highlight the point of view and perceptions of stakeholders on different agroforestry systems and practices. In particular, the paper aims to highlight the needs and opportunities as identified by local stakeholders to increase the resilience and functionality of agroforestry in Italy.

\section{Description of study areas and agroforestry systems}

Within the AGFORWARD project, agroforestry systems were categorized into four categories: a group comprising traditional agroforestry systems of high natural and cultural value, such as wood pasture, and three groups focused on either agroforestry for livestock farmers, arable farmers, or farmers managing high-value trees. In Italy, the PRDN approach has been applied to a three case studies representative of a wood pasture system, and systems of potential interest to either livestock farmers or farmers with olive trees (Fig. 1). The case studies are: 
Grazed oak woodlands in Sardinia

The grazed oak woodland in Sardinia is a Mediterranean semi-natural agro-silvopastoral system where grazing is practiced among trees that are deliberately maintained and managed. In Mediterranean area, Dehesa and Montado systems in Spain and Portugal represent the most common examples (Moreno et al. 2014). In Italy, the study was implemented in Sardinia region, where similar systems characterise the landscape creating a mosaic of agro-silvopastoral systems at different level of complexity (Seddaiu et al. 2013). The silvopastoral system includes both grazed forests and wooded grasslands where scattered Quercus spp. trees are mixed with permanent or temporary pastures or intercropped with cereals and/or fodder crops.

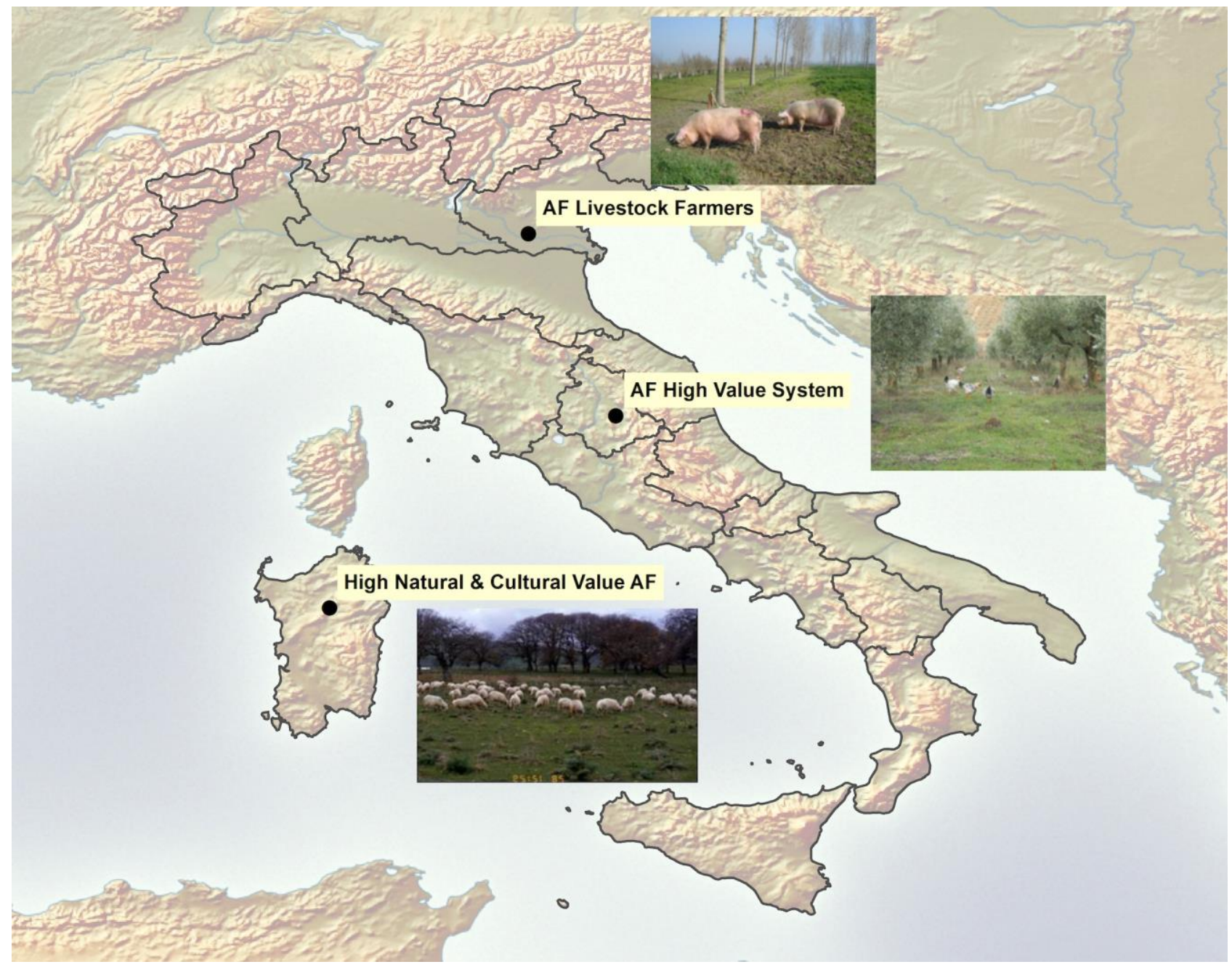

Figure 1 Map of Italy. Locations of agroforestry systems and workshops in Italy.

Intercropping and grazing into olive orchards in Umbria

In the Mediterranean, olive trees (Olea europaea L.) are often used in traditional agroforestry systems. The case study in the central Umbria region focused on the intercropping of wild asparagus (Asparagus acutifolius L.) in olive orchards, since this species naturally tends to grow in abandoned olive orchards and has been already established as valuable on the market (Aliotta et al. 2004; Benincasa et al. 2007). Grazing animals, in particular poultry, can provide further source of income, in addition to their function for weed control and fertilization, thus lowering costs and impacts of orchard management. 
Free-range pigs and energy crops in Veneto

Livestock production systems, either grazing ruminants, pigs and poultry, can produce negative environmental externalities including methane, nitrous oxide and ammonia production (Burgess and Morris 2009). Integrating trees in such systems can help mitigate greenhouse gas emissions and ammonia release, helping store carbon and control odour. Moreover, trees can promote animal welfare providing shade especially during the hot summers. In Italy, the study was implemented in Veneto region and was focused on the free-range pigs with bordering areas of short rotation poplar and willow which could be used for bioenergy.

\section{Materials and methods}

The Participatory Research for Development Network approach

The Participatory Research for Development Network (PRDN) is a participatory research method defined as a process that combines research, education, and action (Khanloua and Peter 2005). It is finalized to shorten the gap between the researcher and research object but also to actively involve stakeholders into the study context. This approach aims to get new knowledge and introduce changes in the social environment where the study is performed (Rapanà 2005). Its origins are rooted in developing country areas (Park 1993) but variations of participatory research have been developed in different settings (Brown and Tandon 1983). Participatory research represents a pool of concepts, practices, norms and attitudes enabling people to enhance their knowledge for sustainable agriculture and natural resource management (Reason and Bradford 2008). The method directly involves stakeholders and end-users in defining all the aspects of the research process so that they contribute expertise and share decision making, while allowing researchers to better understand the role of technology in complex systems (Martin and Sherington, 1997). Farmers and end-users' involvement in the development of more appropriate technologies provides the opportunity for feedback and adjustment according to farmers' criteria and facilitates local adaptation to particular environmental and socio-economic conditions.

The workshops carried out in Italy

The PRDN protocol was agreed and shared among the AGFORWARD partners. Workshops were organised in each partner country, in a specific experimental site or farm practising agroforestry. In Italy three workshops focusing on the above described agroforestry systems were organised and conducted between June and September 2014.

A total number of 48 stakeholders participated at the workshops carried out in Sardinia (13 participants), Umbria (13 participants) and Veneto (22 participants). The objective of each workshop was to better understand and further develop the functioning of traditional and/or novel agroforestry practices and systems. The workshops comprised group discussions organized into sessions of knowledge exchange between stakeholders and scientists so that it was possible to evidence actual knowledge gaps - i.e. 'what has to be tested', 'what is not known yet'- from what just needed to be changed. Different representatives of local stakeholders participated in the workshops.

Data collection

In each workshop, qualitative and quantitative data were collected. In the first phase, stakeholders participated in moderated discussions on the challenges and issues of current agroforestry systems and practices in order to highlight key opinions and priorities (qualitative data). Participants were also invited to 
highlight the research gaps to be addressed by the project activities, according to their experience and knowledge.

In the second phase, stakeholders were asked to fill a questionnaire aimed at eliciting their perceptions and opinions on positive and negative aspects of agroforestry systems (quantitative data). Forty-five issues divided into four categories (production, management, environment and socio-economy) were used to design the questionnaire (Table 1). Stakeholders were asked to rank the most positive and negative issues up to a maximum of 10 positive and 10 negative issues across all the four categories.

Table 1 Examined agroforestry issues grouped into four categories

\begin{tabular}{|c|c|c|c|}
\hline Category & Issues & Category & Issue \\
\hline Production & $\begin{array}{l}\text { Animal health and welfare } \\
\text { Animal production } \\
\text { Losses by predation } \\
\text { Crop or pasture production } \\
\text { Crop or pasture quality/food safety } \\
\text { Disease and weed control } \\
\text { Diversity of products } \\
\text { Timber/wood/fruit/nut production } \\
\text { Timber/wood/fruit/nut quality }\end{array}$ & Environment & $\begin{array}{l}\text { Biodiversity and wildlife habitat } \\
\text { Carbon sequestration } \\
\text { Change in fire risk } \\
\text { Climate moderation } \\
\text { Control of manure/noise/odour } \\
\text { General environment } \\
\text { Landscape aesthetics } \\
\text { Reduced groundwater recharge } \\
\text { Runoff and flood control } \\
\text { Soil conservation } \\
\text { Water quality }\end{array}$ \\
\hline Management & $\begin{array}{l}\text { Complexity of work } \\
\text { Inspection of animals } \\
\text { Labour } \\
\text { Management costs } \\
\text { Mechanisation } \\
\text { Originality and interest } \\
\text { Project feasibility } \\
\text { Tree regeneration/survival }\end{array}$ & $\begin{array}{l}\text { Socio- } \\
\text { Economy }\end{array}$ & $\begin{array}{l}\text { Administrative burden } \\
\text { Business opportunities } \\
\text { Cash flow } \\
\text { Farmer image } \\
\text { Income diversity } \\
\text { Inheritance and tax } \\
\text { Regulation } \\
\text { Local food supply } \\
\text { Marketing premium } \\
\text { Market risk } \\
\text { Opportunity for hunting } \\
\text { Profit } \\
\text { Relationship between farmer/hunter } \\
\text { Relationship between farmer/owner } \\
\text { Rural employment } \\
\text { Subsidy and grant eligibility } \\
\text { Tourism }\end{array}$ \\
\hline
\end{tabular}

\section{Questionnaire data analysis}

Forty eight takeholders ( 39 males, 9 females; $42 \%$ aged between $36-50$ years and $46 \%$ aged between $51-65$ years) completed the questionnaire. The data analysis was performed considering the responses of: the total number of stakeholders; stakeholders grouped according to professional categories (24 farmers, 17 policy-makers, 7 researchers), and grouped according to the three workshops (13 respondents in Sardinia, 13 respondents Umbria, 22 respondents Veneto). Agroforestry issues were analyzed both as single items and within four categories: production, management, environment and socio-economics. All the stakeholders' responses to positive and negative perceptions of agroforestry issues were registered and classified according to a score indicating the level of importance attributed to an issue. The level of positive or negative perception of an issue was expressed as "Very High" (VH) when the score ranged between 1 
and 4, "High" (H), with score ranging between 5 and 7, "Quite low" (QL) with score between 8 and 10, and "Very low" (VL) when no answer was given (even if this response could also express a very doubtful opinion in relation to a certain issue which is not enough known or experienced by the respondent). Different weights were assigned to each score: $\mathrm{VH}=4 ; \mathrm{H}=3 ; \mathrm{QL}=2 ; \mathrm{VL}=1$. The mean of weighted scores of each issue was calculated considering the total score (obtained from the sum of the frequency of answers per each score class multiplied by the value of the relative score class) divided by the total number of respondents. Statistical analysis was performed with opensource R free software (https://www.rproject.org/). The Wilconxon test, a non-parametric statistical hypothesis test for comparing matched samples, was applied in order to assess the differences (5\% significance level) between positive and negative responses both on categories of issues and on each single issue. The Kruskal-Wallis nonparametric test for comparing independent samples was used to assess the differences ( $5 \%$ significance level) among groups of stakeholders in attributing scores (negative and positive responses). Only the data showing statistically significant differences are reported in this paper.

\section{Results}

Key issues, challenges and innovation

In each workshop, stakeholders were invited to reflect on and discuss about challenges and issues of current agroforestry systems and practices. The participants highlighted priority issues and opinions on the three specific agroforestry systems, as well as the main constraints and further issues to be investigated. A comprehensive scheme of challenges and issues as emerged from the analysis of the discussions conducted during the three workshops is reported in Fig.2. One of the stakeholders' indications in the three agroforestry systems studied was that, the animal component in particular (common to the three systems) needs further investigation in relation to management and economic valuation in order to raise the stakeholders' awareness of agroforestry roles and functions.

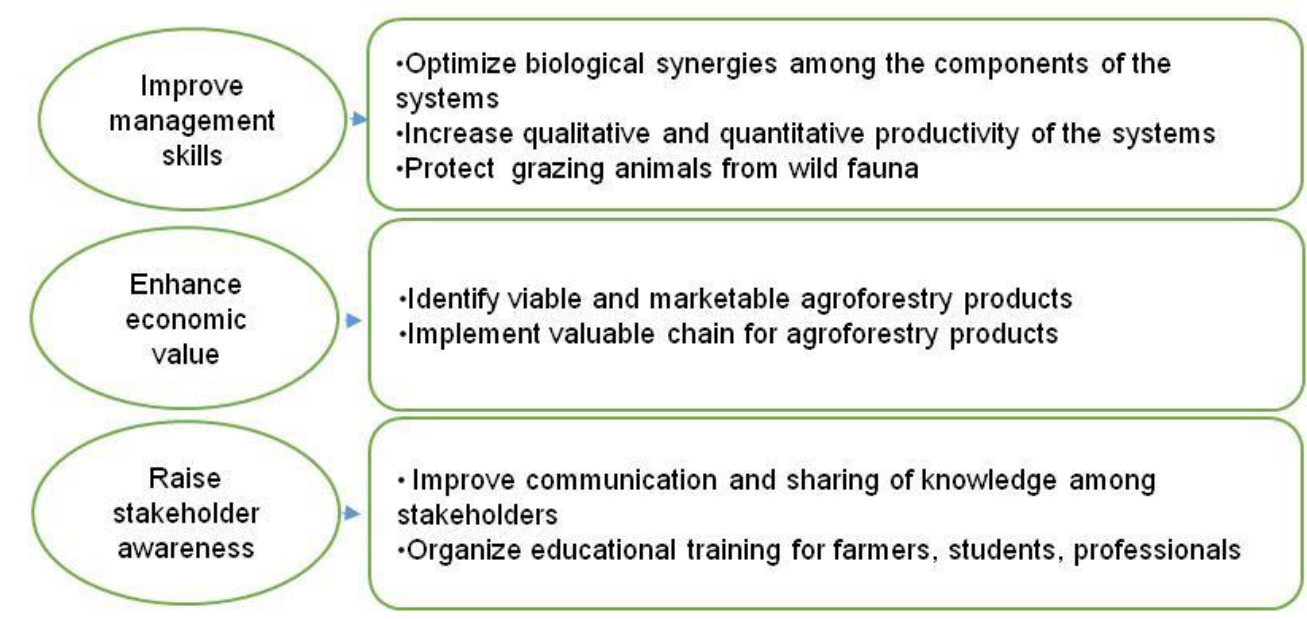

Fig 2 Scheme of main results of workshops' discussions. Challenges and key issues from the stakeholders' discussions during the workshops 
Management skills

Stakeholders prioritized the optimization of the biological synergies among grazing animals, pasture characteristics and trees species as most important management issue. Pastures should guarantee a balanced and high quality feed for grazing animals. Tree varieties, tree spacing and density need to be modulated to allow both the natural regeneration of the woody species and the persistence of the pasture. Stakeholders highlighted the need to increase the productivity of the silvopastoral system, specifically the forage availability, and to assess the appropriate stocking rate to ensure system resilience. In order to produce high quality products, apposite management strategies should prioritize the improvement of the qualitative value of the pasture. Among the management key issues to be more deeply studied, stakeholders highlighted the need to protect grazing animals from wild fauna. The problems caused by high densities of protected wild animals, predators, especially wolves, but also boars and deers, is becoming a very serious problem in many Italian rural and marginal areas where silvopastoral systems are extensively managed and animals, especially sheep, are usually free to graze in open fields. Farmers and landowners are often forced to reduce the free-grazing period, recovering the animals during the night. On the other hand, the high presence of boars and deers affects the livestock management, reducing the pasture availability either by damaging the herbaceous layer or heavily grazing it. This creates higher labour costs and problems with securing animal feed.

Economic value and legal and administrative burden

The multifunctional nature of agroforestry results in various goods and benefits. The stakeholders considered that the extensive management of silvopastoral systems improves the quality of the animal products, but that the management costs were higher than those in more intensive livestock systems. The stakeholders see the need for a label to certify the agroforestry origin of the products to cover the higher management costs, and the need to increase the value of products from agroforestry through the food supply chain. The improvement of the local supply chain should consider the market channels used for smallholder productions, the marketing problems faced by farmers and the opportunities to improve the quality and quantity of agroforestry products. In small-scale farms, the development of facilities to process meat would retain the value added close to the farm.

Stakeholders also observed that the bureaucratic complexity of CAP discourages farmers from applying for grants. For example, farmers perceived that trees in fields were obstacles because they caused the reduction of single farm payments. Stakeholders thus supported the development of appropriate tools to facilitate the access to public subsidies available in the CAP to increase the protection of the rural lands and add value to positive externalities.

\section{Stakeholders' awareness}

Stakeholders highlighted the need to create communication tools (such as technical papers, seminars, and demonstrations) to share knowledge on agroforestry. Moreover, professionals and technicians required training in order to provide technical, financial and marketing assistance on agroforestry to landowners. Farmers expressed the need to be assisted in identifying and establishing field trials of best practices responding to specific environmental and socio-economic characteristics of their territory. Monitoring and evaluation was thought to help determine the impacts, benefits, and outcomes of agroforestry practices as well as helping to guide future development. 


\section{Stakeholders perceptions of agroforestry}

The quantitative data analysis showed that there were differences in the positive and negative weighting given to the production, management and environmental aspects of agroforestry, while no differences were observed related to the socio-economic category (Table 2). Higher mean positive weighted scores, than negative scores, were observed in relation to production and the environment, while higher negative scores were observed in relation to management. The management of agroforestry was negatively perceived by the total sample, groups of stakeholders, and the different workshops (Table 2). There were statistically significant differences between the positive and negative mean weighted scores of responses on most single issues within the whole dataset (Table3). In the production category, most issues were rated positively, but "loss by predation" was perceived as a negative aspect of agroforestry by all stakeholders grouped together, by farmers, and the workshops at Umbria and Veneto. Most of the management issues related to agroforestry were rated negatively except "originality and interest". Among the socio-economic issues the most negative are "administrative burden", "regulation", "subsidy and grant eligibility" and "market risk". As far as the environmental issues are concerned only "Reduced groundwater recharge" is rated as negative.

Table 2 Positive and negative scores related to production, management, environmental characteristics of agroforestry by: the total number of stakeholders; professional groups; workshops. Only data showing statistically significant differences are reported. Wilcoxon test, $P \leq 0.05$

\begin{tabular}{|c|c|c|c|c|c|}
\hline \multirow[t]{2}{*}{ Stakeholder } & & \multicolumn{3}{|c|}{ Weighted mean score } & \multirow[t]{2}{*}{$P$} \\
\hline & & Positive attribute & Negative attribute & Difference & \\
\hline \multirow[t]{3}{*}{ All } & Production & 1.85 & 1.38 & 0.47 & $<0.01$ \\
\hline & Management & 1.35 & 1.82 & -0.47 & $<0.01$ \\
\hline & Environment & 1.55 & 1.24 & 0.31 & $<0.01$ \\
\hline \multirow[t]{3}{*}{ Farmers } & Production & 1.82 & 1.54 & 0.28 & $<0.01$ \\
\hline & Management & 1.37 & 1.75 & -2.62 & $<0.01$ \\
\hline & Environment & 1.42 & 1.24 & 0.18 & $<0.01$ \\
\hline \multirow[t]{3}{*}{ Policy makers } & Production & 1.75 & 1.22 & 0.53 & $<0.01$ \\
\hline & Management & 1.25 & 1.91 & -0.66 & $<0.05$ \\
\hline & Environment & 1.55 & 1.21 & 0.34 & $<0.01$ \\
\hline Researchers & Management & 1.09 & 1.83 & -0.74 & $<0.05$ \\
\hline \multirow{3}{*}{$\begin{array}{l}\text { Sardinia } \\
\text { workshop }\end{array}$} & Production & 1.72 & 1.29 & 0.43 & $<0.01$ \\
\hline & Management & 1.18 & 1.72 & -0.54 & $<0.05$ \\
\hline & Environment & 1.59 & 1.27 & 0.32 & $<0.05$ \\
\hline $\begin{array}{l}\text { Umbria } \\
\text { workshop }\end{array}$ & Production & 1.69 & 1.43 & 0.26 & $<0.05$ \\
\hline \multirow{3}{*}{$\begin{array}{l}\text { Veneto } \\
\text { workshop }\end{array}$} & Production & 1.85 & 1.41 & 0.44 & $<0.01$ \\
\hline & Management & 1.17 & 1.94 & -0.77 & $<0.01$ \\
\hline & Environment & 1.41 & 1.14 & 0.27 & $<0.01$ \\
\hline
\end{tabular}


Table 3 Statistically significant differences between the positive and negative mean weighted scores attributed to each issue by all stakeholders, the stakeholders grouped by profession, and grouped by workshop.

\begin{tabular}{|c|c|c|c|c|c|c|c|}
\hline Issue & All & Farmers & $\begin{array}{l}\text { Policy } \\
\text { makers }\end{array}$ & $\begin{array}{l}\text { Resea } \\
\text { rchers }\end{array}$ & $\begin{array}{l}\text { Sardinia } \\
\text { workshop }\end{array}$ & $\begin{array}{l}\text { Umbria } \\
\text { workshop }\end{array}$ & $\begin{array}{l}\text { Veneto } \\
\text { workshop }\end{array}$ \\
\hline \multicolumn{8}{|l|}{ Production } \\
\hline Animal health and welfare & 0.79 & & 0.34 & & 1.54 & 1.00 & 1.09 \\
\hline Animal production & 0.65 & & & & & & \\
\hline Losses by predation & -0.77 & -0.33 & & & & -1.15 & -1.00 \\
\hline $\begin{array}{l}\text { Crop and pasture quality/food } \\
\text { safety }\end{array}$ & 0.1 & 0.37 & -0.09 & & & & 1.45 \\
\hline Diversity of products & 1.37 & 1.08 & 0.54 & & 1.53 & & 1.45 \\
\hline Timber/wood/fruit/nut production & 0.97 & 0.58 & 0.36 & 1.85 & 1.31 & & 1.47 \\
\hline \multicolumn{8}{|l|}{ Management } \\
\hline Complexity of work & -1.28 & -0.62 & -0.51 & & -1.07 & & -1.68 \\
\hline Inspection of animals & -1.11 & 0.04 & -0.20 & & & & -1.77 \\
\hline Management costs & -0.54 & & -0.95 & & & & -0.49 \\
\hline Mechanisation & -0.59 & 0.12 & & & & & -0.59 \\
\hline Originality and interest & 0.68 & 0.12 & 0.50 & & & & 1.13 \\
\hline Tree regeneration/survival & -1.14 & -0.12 & -0.13 & -0.43 & & & -2.27 \\
\hline \multicolumn{8}{|l|}{ Environment } \\
\hline Biodiversity and wildlife habitat & 1.00 & & 0.74 & & & & 1.18 \\
\hline Carbon sequestration & & & & & & & 0.45 \\
\hline Change in fire risk & 0.48 & & 0.58 & & 1.72 & & \\
\hline General environment & 0.87 & 0.47 & 0.41 & & & & 0.81 \\
\hline Landscape aesthetics & 0.58 & & 0.07 & & 1.15 & & 0.50 \\
\hline Reduced groundwater recharge & -0.29 & & -0.08 & & & & -0.64 \\
\hline Soil conservation & & & & & & & 0.63 \\
\hline \multicolumn{8}{|l|}{ Socio-economy } \\
\hline Administrative burden & -0.87 & & & & -1.00 & & -1.13 \\
\hline Business opportunities & 0.52 & & & & & & \\
\hline Farmer image & 0.82 & & & & & 1.07 & 0.90 \\
\hline Income diversity & 1.09 & & 0.29 & & 1.30 & 0.85 & 0.90 \\
\hline Regulation & -0.72 & & -0.08 & & & & -0.77 \\
\hline Local food supply & 0.48 & & -0.11 & & & & 0.77 \\
\hline Marketing premium & 0.32 & & & & & & 0,63 \\
\hline Market risk & -0.69 & & & & & & -1.00 \\
\hline $\begin{array}{l}\text { Relationship between } \\
\text { farmer/hunter }\end{array}$ & -0.3 & & & & & & \\
\hline Subsidy and grant eligibility & -0.33 & & -0.07 & & & & -0.77 \\
\hline Tourism & 0.77 & & 1.67 & & & & 086 \\
\hline
\end{tabular}

Figures with negative precursor refer to more negative perceptions. Only the data showing statistically significant differences are reported. Wilcoxon test, $P \leq 0.05$

When the results of the farmers, the policy makers, and the researchers within a workshop were compared, there were no statistically significant differences in positive and negative scores in relation to the four categories of issues (data not reported). However, across the three workshops, farmers and policy makers attributed higher positive scores to production benefits than researchers, while policy makers and researchers gave higher positive scores to environmental benefits than farmers (Table 4). Policy makers also assumed that the negative impact of agroforestry on management was greater than that by farmers and researchers (Table 4). 
Table 4 Weighted mean scores attributed by farmers, policy makers and researchers on the positive and negative perceptions of agroforestry in relation to: production, environment, management.

\begin{tabular}{lllll}
\hline Category & \multicolumn{3}{l}{ Weighted mean score } & \\
\cline { 2 - 4 } & Farmers & Policy makers & Researchers & \\
\hline Positive perceptions & & & & \\
$\quad$ Production & 1.82 & 1.75 & 1.68 & $<0.01$ \\
$\quad$ Environment & 1.42 & 1.55 & 1.51 & $<0.01$ \\
\hline $\begin{array}{l}\text { Negative perceptions } \\
\quad \text { Management }\end{array}$ & 1.76 & 1.91 & 1.84 & $<0.01$ \\
\hline
\end{tabular}

Socio-economic category is not reported since the three groups did not show differences among positive and negative perceptions. Only the data showing statistically significant differences are reported. Kruskal-Wallis test, $P \leq 0.05$

There were significant differences in the positive and negative weighting given to specific issues between the three workshops (Table 5). The benefits of agroforestry on "crop and pasture production" was perceived higher at the Umbria workshop, than at others, whilst "disease and weed control" was perceived most positively in Veneto. The average weighted score of timber/wood/fruit/nut production and quality was higher in Sardinia than in Umbria. The issues "inspection of animals" and "labour" were perceived as more positive at the Umbria workshop, while "originality and interest" was most highly ranked at the Veneto and Umbria workshop. "Project feasibility" and "profit" were perceived as more positive at the Umbria workshop. Participants at the Sardinian workshop seemed to show a much higher perception of the positive effects of agroforestry in terms of "change in fire risk" and "landscape aesthetics" in comparison to participants at the other sites.

Table 5 Means of weighted scores attributed by three workshops to the positive and negative perceptions of agroforestry issues

\begin{tabular}{|c|c|c|c|c|c|}
\hline \multirow[t]{2}{*}{ Category } & \multirow[t]{2}{*}{ Issue } & \multicolumn{3}{|c|}{ Mean weighted score } & \multirow[t]{2}{*}{$P$} \\
\hline & & Sardinia & Umbria & Veneto & \\
\hline \multicolumn{6}{|c|}{ Positive perceptions } \\
\hline \multirow[t]{4}{*}{ Production } & Crop and pasture production & 1 & 2.15 & 1 & $<0.01$ \\
\hline & Disease and weed control & 1 & 1.53 & 1.90 & $<0.05$ \\
\hline & Timber/wood/fruit/nut production & 2.46 & 1.23 & 2.27 & $<0.05$ \\
\hline & Timber/wood/fruit/nut quality & 1.77 & 1.23 & 1 & $<0.05$ \\
\hline \multirow[t]{4}{*}{ Management } & Inspection of animals & 1 & 1.61 & 1 & $<0.05$ \\
\hline & Labour & 1 & 1.53 & 1 & $<0.05$ \\
\hline & Originality and interest & 1 & 1.76 & 2.13 & $<0.05$ \\
\hline & Project feasibility & 1 & 1.84 & 1 & $<0.01$ \\
\hline \multirow[t]{2}{*}{ Environment } & Change in fire risk & 2.77 & 1.23 & 1 & $<0.01$ \\
\hline & Landscape aesthetics & 2.38 & 1.38 & 1.5 & $<0.05$ \\
\hline Socio-economy & Profit & 1 & 1.54 & 1 & $<0.05$ \\
\hline \multicolumn{6}{|c|}{ Negative perceptions } \\
\hline \multirow[t]{3}{*}{ Production } & Animal health and welfare & 1.15 & 1.23 & 2.54 & $<0.01$ \\
\hline & Losses by predation & 1.15 & 2.38 & 2 & $<0.05$ \\
\hline & Crop and pasture production & 1.38 & 1.23 & 1 & $<0.05$ \\
\hline Management & Tree regeneration/survival & 2 & 1.38 & 3.27 & $<0.01$ \\
\hline \multirow[t]{2}{*}{ Environment } & Runoff and flood control & 1.92 & 1.23 & 1 & $<0.01$ \\
\hline & Reduced groundwater recharge & 1.15 & 1.23 & 2 & $<0.05$ \\
\hline Socio-economy & Inheritance and tax & 1.07 & 1.61 & 1 & $<0.01$ \\
\hline
\end{tabular}

Only the data showing statistically significant differences are reported. Kruskal-Wallis test, $P \leq 0.05$ 
As far as the negative perceptions, even though the stakeholders in Veneto showed a positive perception of "animal health and welfare" issue (Table 3), they seemed to show more negative perceptions in relation to this issue and "tree regeneration and survival" than participants at the other sites (Table 5). "Losses by predation" and "inheritance and tax" were perceived as more negatively by the participants in Umbria than at other sites, while the stakeholders in Sardinia showed a more negative perceptions of agroforestry in terms of "runoff and flood control".

In terms of single issues, the professional stakeholder groups generally showed similar responses to positive aspects, although researchers and policy makers showed greater positive weightings for "biodiversity and wildlife" and farmers showed greater positive weightings for "business opportunities" (Table 6). In terms of negative issues, farmers placed higher negative weighting on "losses by predation" and "management costs" than policy makers and researchers, and researchers placed a greater negative weighting on mechanization than policy makers (Table 6).

Table 6 Mean weighted scores attributed by farmers, policy makers and researchers on the positive and negative perceptions of agroforestry issues.

\begin{tabular}{|c|c|c|c|c|c|}
\hline \multirow[t]{2}{*}{ Category } & \multirow[t]{2}{*}{ Issue } & \multicolumn{3}{|c|}{ Mean weighted score } & \multirow[t]{2}{*}{$P$} \\
\hline & & Farmers & Policy makers & Researchers & \\
\hline \multicolumn{6}{|c|}{ Positive perceptions } \\
\hline Environment & Biodiversity and wildlife habitat & 1.7 & 2.53 & 2.83 & $<0.05$ \\
\hline Socio-economy & Business opportunity & 2.04 & 1 & 1 & $<0.01$ \\
\hline \multicolumn{6}{|c|}{ Negative perceptions } \\
\hline Production & Losses by predation & 1.45 & 1.11 & 1 & $<0.05$ \\
\hline \multirow[t]{2}{*}{ Management } & Management costs & 2.33 & 1.76 & 1.14 & $<0.05$ \\
\hline & Mechanisation & 1.12 & 1 & 1.28 & $<0.05$ \\
\hline
\end{tabular}

Only the data showing statistically significant differences are reported. Kruskal-Wallis test, $P \leq 0.05$

\section{Discussion}

The quantitative data shows that overall stakeholders perceived positive impacts of agroforestry in terms of production and the environment, a negative impact in terms of management, with no clear pattern in terms of socio-economic effects. These results confirm that management issues are a potential obstacle to be addressed when establishing or conducting agroforestry practices. This result is supported by the qualitative data provided by stakeholders in the three workshops which highlighted the need for management skills to optimize the different components. At the same time, the quantitative results demonstrate the perceived benefits in terms of production and the environment even though, according to stakeholders' discussions, productivity still needs to be improved.

Stakeholders showed general agreement on the positive and negative opinions of agroforestry in terms of four overall categories of issues, and this was not generally dependent on the type of agroforestry being considered, except for the Umbria stakeholders who did not show any clear positive or negative opinion regarding the environment. The farmers, policy makers and researchers also generally showed similar rankings, although farmers showed more positive perceptions in terms of production than researchers, and policy makers perceived more positive environmental effects and negative management effects than farmers.

In Sardinia, "change in fire risk" and "landscape aesthetics" are perceived as more positive attributes of agroforestry than at the other two sites. The higher scores can be explained by the established role of the grazing component of silvopastoral systems in safeguarding the environment from fires (Riedel et al. 2007; Ruiz-Mirazo et al. 2009; Franca et al. 2012), particularly through the controlled 
grazing of firebreaks (Ruiz-Mirazo et al. 2011). The result confirms what is widely reported in literature (Bernués et al. 2011; Ripoll-Bosch et al. 2012) on the relevant positive perceptions of local stakeholders on the function of grazing practices and sheep flocks related to the changes in vegetation and landscape and the risk of fire hazards. The higher perception in Sardinia of the positive landscape effects of agroforestry might be linked to the role of the silvopastoral system in shaping the landscape and creating ecological and cultural diversity (Gibon 2005). In Sardinia, the landscape traditionally integrates trees, sheep grazing and crops, whereas the olive trees with asparagus and poultry system in Umbria is a novel system of limited extent. This could explain the lower weighted scores of stakeholders in Umbria.

The higher negative perception of "animal health and welfare" of Veneto stakeholders in comparison to Umbria and Sardinia stakeholders could be linked to the fact that Veneto breeders have more recently adopted agroforestry practices and have the perception of animals being less protected (i.e. during winter) with the extensive system in comparison with the intensive one they had been used until recent times.

When stakeholders' perceptions are analyzed according to their professional categories, researchers and policy makers expressed higher positive perceptions on agroforestry in terms of safeguarding biodiversity and wildlife habitat. The scientific evidence of the beneficial effects of agroforestry on biodiversity is widely reported (Lorenz and Rattan 2014). The sensitivity of researchers and policy makers towards environmental benefits may be a result of these groups having a deeper knowledge and stronger awareness, than farmers, about the positive impact of agroforestry systems on biodiversity. By contrast, farmers more positively perceived the business opportunities from adopting agroforestry. Multifunctional systems and product diversification can increase agricultural resilience (Lin 2011) and farmers can more easily and directly appreciate the business opportunities on their specific farm. Ponisio et al. (2015) and Van der Sluijs et al. (2015) report that diversification can support biodiversity and if it is possible to optimize biodiversity without reducing profitability (De Sousa et al. 2015), thus there is a benefit in supporting activities to better inform farmers and professionals on agroforestry.

There seems to be a correspondence between the stronger positive perception of the product quality and the food safety issues experienced mainly by farmers and what has been elicited during the workshops' discussions. As far as the "timber/wood/fruit/nut production" is concernedthe positive ranking ,makes assuming that the presence of trees is generally not perceived by the whole sample of stakeholders as a real obstacle. Despite that during the discussions stakeholders highlighted the need to improve the tree management through both agronomic and economic solutions to make agroforestry practices easier for farmers.

The "subsidies and grant eligibility" issue, related to maintaining the eligibility of a system for single farm payments and the uptake on grants to establish new systems, was perceived as a negative issue by all stakeholders both in quantitative and the qualitative findings where stakeholders complained about the complexity of the CAP. The need for implementing European policies supporting agroforestry is clear and must be supported by AF stakeholders themselves also through the improvement of their awareness of AF benefits (Pisanelli et al. 2012) .

The negative perception related to the losses caused by predation is understandably higher in farmers than in policy makers and researchers since farmers, especially in recent times, have been complaining about the loss of crops, pastures and livestock due to predation and overall disturbance from wild fauna.

While management costs are felt by policy makers and by Veneto participants as a constraint, mechanization is thought to be negatively related to agroforestry practices more by Veneto stakeholders, confirming that this group of stakeholders dealing with a kind of agroforestry system still needs to adapt to the presence of trees. 
Stakeholders generally shared similar perceptions of the benefits and constraints of agroforestry: in part this may be a result of the participants being self-selected as the participants were those who attended initial stakeholder workshops on agroforestry. The positive attributes of agroforestry were mainly associated with production and the environment; the negative aspects were associated primarily with management. Nevertheless, this work has provided specific indications of what is needed according to the perspectives of groups of users, and has contextualized particular needs related to issues in relation to the characteristics of a certain agroforestry system. The last observation can be evaluated as much more important in Italy because of the wide variability of the agriculture landscapes and possible combinations of their rural uses and functions.

Stakeholders' point of view on agroforestry systems, based on their experiences and competences, can enable future research, consequently stimulating decision makers to more accurately read and interpret the socio-economic and cultural contexts of rural areas. This, in turn, would provide proper policy tools to support the development of viable and sustainable agroforestry systems.

This study demonstrates the validity of the participatory approach to address the complexity of agroforestry systems. The PRDN methodology allowed the integration of qualitative and quantitative information and proves to be an effective set of research tools, enabling the comprehension of the multifaceted functions of agroforestry systems in the development process of rural areas.

The results of this work suggest the need to improve policies related to agroforestry, to provide information on specific agroforestry issues, and to support initiatives to be promoted by policy-makers and researchers such as organizing training courses for farmers and information events addressed at raising public awareness on agroforestry.

Acknowledgements We acknowledge support of the European Commission through the AGFORWARD FP7 research project (contract 613520). The views and opinions expressed in this report are purely those of the writers and may not in any circumstances be regarded as stating an official position of the European Commission. We express our gratitude to Dr. Agnese Panzera and Dr. Chiara Camerota of the Dept. of Statistics, Informatics, Applications "Giuseppe Parenti" of the University of Florence for their support in statistical analysis.

\section{References}

Aliotta G, Aceto S, Farina A, Gaudio L, Rosati A, Sica M, Parente A (2004) Natural history, cultivation and biodiversity assessment of Asparagus. In De Cortes Sanchez-Mata M and Tardio J (ed) Research advance in agriculture and food chemistry, 5: 1-12 (Ed. Global research network)

Barbieri C, Valdivia C (2010) Recreation and agroforestry: Examining new dimensions of multifunctionality in family farms. Journal of Rural Studies 26: 465-473

Benincasa P, Tei F, Rosati A (2007) Plant density and genotype effects on wild asparagus (Asparagus acutifolius L.) spear yield and quality. HortScience 42(5):1163-1166

Bernués R, Ruiz A, Olaizola D, Villalba I, Casasús L (2011) Sustainability of pasture-based livestock farming systems in the European Mediterranean context: Synergies and trade-offs Livestock Science 139: 4457

Brown LD, Tandon R (1983) Ideology and Political Economy In Inquiry: Action Research and Participatory Research The Journal of Applied Behavioural Science 19: 277-294

Burgess PJ, Morris J (2009) Agricultural technology and land use futures: the UK case. Land Use Policy 26S: S222-S229

Burgess PJ, Crous-Duran J, Den Herder M, Dupraz C, Fagerholm N, Freese D, Garnett K, Graves AR, Hermansen JE, Liagre F, Mirck J, Moreno G, Mosquera-Losada MR, Palma JHN, Pantera A, Plieninger 
T, Upson M (2015) AGFORWARD Project Periodic Report: January to December 2014. Cranfield University: AGFORWARD. $95 \mathrm{pp}$

Council Regulation (EC) No 1698/2005 of 20 September 2005 on support for rural development by the European Agricultural Fund for Rural Development (EAFRD). Accessed 29 may 2017 http://eurlex.europa.eu/legal-content/EN/TXT/PDF/?uri=CELEX:32005R1698\&from=en

De Sousa XAM, De Belém Costa FM, De Sousa Fragoso RM (2015) Management of Mediterranean forests. A compromise programming approach considering different stakeholders and different objectives Forest Policy and Economics 57: 38-46

Dupraz C, Burgess PJ, Gavaland A, Graves AR, Herzog F, Incoll LD, Jackson N, Keesman K, Lawson G, Lecomte I, Mantzanas K, Mayus M, Palma J, Papanastasis V, Paris P, Pilbeam DJ, Reisner Y, van Noordwijk M, Vincent G, van der Werf W (2005) SAFE (Silvoarable Agroforestry for Europe) Synthesis Report. SAFE Project (August 2001-January 2005). http://www1.montpellier.inra.fr/safe/english/results/finalreport/SAFE\%20Final\%20Synthesis\%20Report.pdf. Accessed 17 October 2016

Eichhorn MP, Paris P, Herzog F, Incoll LD, Liagre F, Mantzanas K, Mayus M, Moreno G, Papanastasis VP, Pilbeam DJ, Pisanelli A, Dupraz C (2006) Silvoarable systems in Europe - past, present and future prospects. Agroforestry Systems 67: 29-50

Franca A, Sanna F, Nieddu S, Re GA, Pintus GV, Ventura A, Duce PP, Salis M, Arca B (2012) Effects of grazing on the traits of a potential fire in a Sardinian wooded pasture. Options Mediterraneennes, Series A: Mediterranean Seminars 2012 103: 307-312

Gibon A (2005) Managing grassland for production, the environment and the landscape. Challenges at the farm and the landscape level Livest. Prod. Sci. 96: 11-31

Graves AR, Burgess PJ, Palma JHN, Herzog F, Moreno G, Bertomeu M, Dupraz C, Liagre F, Keesman K, Van der Werf W, Koeffeman de Nooy A, Van den Briel JP (2007) Development and application of bioeconomic modelling to compare silvoarable, arable and forestry systems in three European countries. Ecological Engineering 29: 434-449

Jose S (2009) Agroforestry for ecocystem services and environmental benefits: an overview. Agrofor Syst, 76:1-10.

Khanloua N, Peter E (2005) Participatory action research: Considerations for ethicalreview. Social Science \& Medicine 60: 2333-2340

Lin BB (2011) Resilience in Agriculture through Crop Diversification: Adaptive Management for Environmental Change. BioScience 61: 183-193

Lorenz K, Rattan L (2014) Soil organic carbon sequestration in agroforestry systems. A review. Agron. Sustain. 34: 443-454

Martin A, Sherington J(1997) Participatory research methods-implementation, effectiveness and institutional context. Agricultural Systems 55(2):195-216

Moreno G, Franca A, Pinto Correia MT, Godinho S (2014) Multifunctionality and dynamics of silvopastoral systems. In Baumont $R$, Carrère $P$, Jouven $M$, Lombardi $G$, López-Francos $A$, Martin $B$, Peeters $A$, Porqueddu (ed): Forage resources and ecosystem services provided by Mountain and Mediterranean grasslands and rangelands. Proceedings of the joint meeting of the "Mountain Pastures, Mediterranean Forage Resources (FAO-CIHEAM) and Mountain Cheese" networks, ClermontFerrand, France, 24-26 June 2014, Options Méditerranéennes, SeriesA: Mediterranean Seminars, 109: 421-436

Nair PKR (1993) An introduction to Agroforestry. Kluwer Academic Publishers (ed), Dordrecht, The Netherlands. $499 \mathrm{pp}$

Nair PKR, Nair VD, Kumar BM, Shawalter JM (2010) Carbon sequestration in agroforestry systems Adv Agron 108: 237-3017 
Palma JHN, Graves AR, Bunce RGH, Burgess PJ, De Filippi F, Keesman KJ, Van Keulen H, Liagre F, Mayus M, Moreno G, Reisner Y, Herzog F (2007) Modeling environmental benefits of silvoarable agroforestry in Europe. Agriculture, Ecosystems and Environment 119: 320-334

Park P (1993) What is participatory research? A theoretical and methodological perspective. In: Park P, Brydin-Miller M, Hall BL, Jackson T (Ed), Voices of change: Participatory research in the United States and Canada, Westport CT: Bergin \& Garvey pp. 1-20.

Pisanelli A, Perali A, Paris P (2012) Potentialities and uncertainties of novel agroforestry systems in the European CAP: farmers' and professionals' perspectives in Italy. L'Italia Forestale e Montana / Italian Journal of Forest and Mountain Environments. doi: 10.4129/ifm.2012.3.07

Pisanelli A, Marandola D, Marongiu S, Paris P, Rosati A, Romano R (2014) The role of development policy in supporting agroforestry systems in EU. Book of abstracts of the 2nd EURAF Conference, Cottbus (Germany) 4-6 June 2014. ISBN: 978-972-97874-4-7, pp. 22-25

Ponisio L C, M'Gonigle L K, Mace K C, Palomino J, de Valpine P and Kremen C (2015) Diversification practices reduce organic to conventional yield gap Proc. R. Soc. B 28220141396

Rapanà F (2005) Metodologia di ricerca partecipata Educazione alla cittadinanza e interculturalità. II Trentino come laboratorio di cittadinanza attiva e differenziata. IPRASE TRENTINO Istituto Provinciale per la ricerca, l'aggiornamento e la sperimentazione educativi. Università degli Studi di Trento, Dipartimento di Scienze della Cognizione e della Formazione.

Reason P, Bradford H (2008) The Sage handbook of action research: participative inquiry and practice SAGE Publications Ltd pp. $752 \mathrm{pp}$

Riedel JL, Casasús I, Bernués A (2007) Sheep farming intensification and utilization of natural resources in a Mediterranean pastoral agro-ecosystem Livestock Science 111: 153 - 163

Ripoll-Bosch R, Díez-Unquera B, Ruiz R, Villalba D, Molina E, Joy M, Olaizola A, Bernués A (2012) An integrated sustainability assessment of mediterranean sheep farms with different degrees of intensification Agricultural Systems 105: 46-56

Rosati A, Caporali S, Paoletti A (2009) Olive, Asparagus and animals: an agroforestry model for temperate climate in developed countries. In: Proceedings of the III OLIVEBIOTEQ (For a renovated, profitable and competitive Mediterranean olive growing sector), Sfax, Tunisia, 15-19 December 2009. ISBN: 978-9938-9513-0-1, pp 229-233

Rossetti I, Bagella S, Cappai C, Caria MC, Lai R, Roggero PP, Martins da Silva P, Sousa JP, Querner P, Seddaiu G (2015) Isolated cork oak trees affect soil properties and biodiversity in a Mediterranean wooded grassland 202: 203-216

Ruiz-Mirazo J, Robles AB, González-Rebollar JL (2009) Pastoralism in Natural Parks of Andalusia (Spain): A tool for fire prevention and the naturalization of ecosystems Options Méditerranéennes A no. 91, Changes in sheep and goat farming systems at the beginning of the 21st century

Ruiz-Mirazo J, Robles AB, González-Rebollar JL (2011) Two-year evaluation of fuelbreaks grazed by livestock in the wildfire prevention program in Andalusia (Spain) Agric. Ecosyst. Environ. 141: 13-22

Seddaiu G, Porcu G, Ledda L, Roggero PP, Agnelli A, Corti G (2013) Soil organic matter content and composition as influenced by soil management in a semi-arid Mediterranean agro-silvo-pastoral system Agriculture, Ecosystems \& Environment, 167: 1-11

Smith B, Wolf J, Martin P (2013) Reconciling productivity with protection of the environment: Is temperate agroforestry the answer? Renewable Agriculture and Food Systems 28: 80-92

Van der Sluijs JP, Amaral-Rogers V, Belzunces LP, Bijleveld van Lexmond M. F. I. J. Bonmatin J-M, Chagnon M, Downs CA, Furlan L, Gibbons DW, Giorio C,Girolami V, Goulson D, Kreutzweiser DP, Krupke C, Liess $M$, Long E, McField M, Mineau P, Mitchell EAD, Morrissey CA, Noome DA, Pisa L, Settele J, Simon-Delso N, Stark JD, Tapparo A, Van Dyck H, Van Praagh J, Whitehorn PR, Wiemers M. (2015) 
Conclusions of the Worldwide Integrated Assessment on the risks of neonicotinoids and fipronil to biodiversity and eco system functioning. Environ Sci Pollut Res (2015) 22:148-154 